\title{
Sulfur Dioxide Effect upon Air Quality in R. Macedonia
}

\author{
Biserka Dimiskovska $^{1}$, Jovan Dimiskovski $^{2}$, Nikola Dimiskovski $^{3}$
}

\begin{abstract}
To evaluate the quality of air, agglomeration zones have been established in R. Macedonia. Two zones (east and west zone) and Skopje region agglomeration have been defined for the main polluting substances: sulfur dioxide (SO2), nitrogen dioxide (NO2), nitrogen oxides (NOx), suspended particles < 10 micrometres in a diameter of (PM10), carbon monoxide (CO) and ozone (O3). Using the available data, the evaluation, the classification of the main polluting substances, the zones and the agglomeration as well as the minimal measurement requirements have been reviewed. To undertake the obligations as to evaluation of air quality and management of heavy metals given in Directive 2004/107/EC, available data on those polluting substances, in this case, sulfur dioxide, have been analyzed. The methods of measurement of different parameters of air quality are given. Emissions of sulfur dioxide and quantity measured are also discussed. Based on the research, a conclusion has been drawn that there are no sufficient data for establishment of zones and agglomerations for heavy metals.
\end{abstract}

Keywords - agglomeration zones, emissions of sulfur dioxide, concentrations of sulfur dioxide

\section{INTRODUCTION}

$\mathrm{I}^{\mathrm{n}}$ $\mathrm{n}$ accordance with the EU directives on quality of air, the member countries are obliged to monitor the air quality in their region by generally accepted methods and principles of evaluation. The requirement as to continuous measurement of the quality of air depends on the level of quality of air and the population in a certain area. Although not an EU member country, Republic of Macedonia has undertaken the obligations in compliance with the EU directives.

\section{Zones and Agglomeration in the Republic of Macedonia}

Republic of Macedonia is located in the central part of the Balkan Peninsula, between $40^{\circ} 50^{\prime}$ and $42^{\circ} 20^{\prime}$ and between $20^{\circ} 27^{\prime}$ and $23^{\circ} 05^{\prime}$. Republic of Macedonia borders on Albania on the west $(191 \mathrm{~km})$, Greece on the South $(262 \mathrm{~km})$, Bulgaria on the east $(165 \mathrm{~km})$ and Serbia on the north $(231 \mathrm{~km})$. The

Biserka Dimiskovska ${ }^{1}$ : University "Ss.Cyril and Methodius", Institute of Eartquake Engineering and Engineering Seismology, Skopje, Republic of Macedonia (Phone: +389-2-3107-173; e-mail:

biserka@pluto.iziis.ukim.edu.mk).

Jovan Dimiskovski2: University "Ss.Cyril and Methodius", Faculty of Mechanical Engineering, Skopje, Republic of Macedonia (Phone: +389-77642-754; e-mail: jovan-rjk@ hotmail.com).

Nikola Dimiskovski": University "Ss.Cyril and Methodius", Faculty of Economics, Skopje, Republic of Macedonia (Phone: +389-77-642-753; email: dimiskovski93@gmail.com). total length of the boundaries is $849 \mathrm{~km}$, while the total area amounts to $25.713 \mathrm{~km}^{2}$.

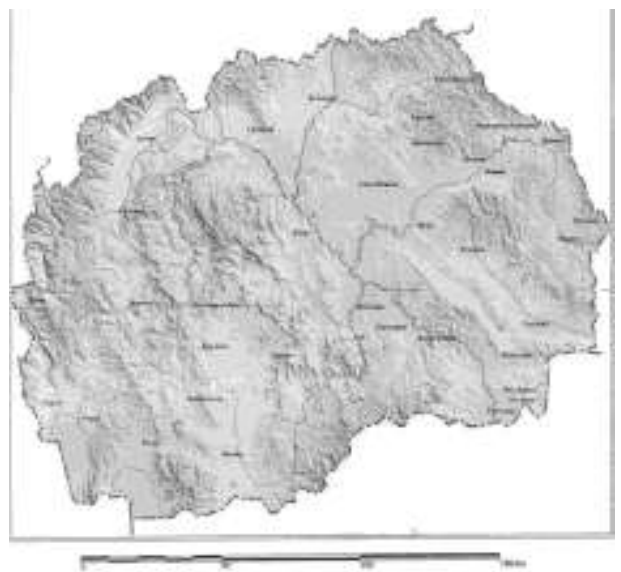

Fig. 1: Geographic map of the Republic of Macedonia

\subsection{Administrative-Territorial Division and Population}

Macedonia has a population amounting to 2.052 .722 (info dated 2011) out of whom $60 \%$ live in urban areas. The average density of the population is 79,8 inhabitants $/ \mathrm{km}^{2}$. A large percentage of the population live in larger towns, namely: Skopje - 530.258 inhabitants, Bitola - 93.646, Kumanovo 107.211, Prilep - 76.427 and Tetovo - 89.513 (statistic data from 2011). The non-uniform distribution of industrial capacities and the inadequate communal infrastructure pose serious problems in providing a high quality environment.

\subsection{Zones and agglomerations for $\mathrm{SO}_{2}, \mathrm{CO}, \mathrm{NO}_{2}, \mathrm{NOx}$, $\mathrm{PM}_{10}$ and $\mathrm{O}_{3}$}

Within the preceding working project "Improvement of Air Quality", there has been given and adopted the proposal for establishment of two zones and one agglomeration for the main polluting substances in the Republic of Macedonia Figure 2. 


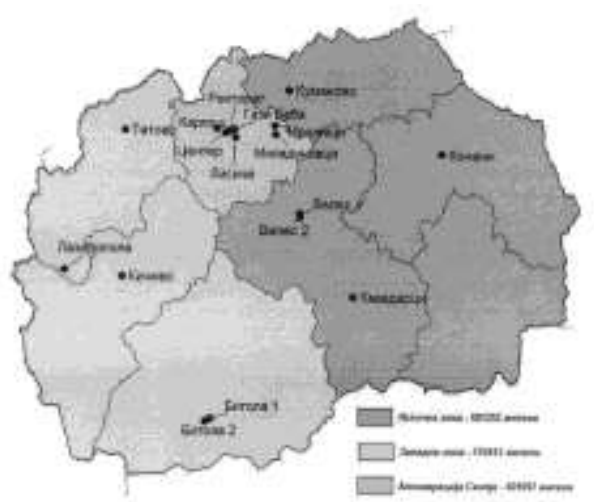

Fig. 2: Zones and agglomeration in the Republic of Macedonia

The zones have been defined as follows: West Zone (consisting of the South-west, Polog and Pelagonia statistic region) and East Zone (composed of Norht-east, South-east, Vardar and East statistic regions) as well as one agglomeration (Skopje statistic region).

TABle I: MAIN DATA Per Zone

\begin{tabular}{|c|c|c|c|c|}
\hline $\begin{array}{l}\text { Zones/agglo } \\
\text { meration }\end{array}$ & $\begin{array}{l}\text { Statistic } \\
\text { regions }\end{array}$ & $\begin{array}{l}\text { Number of } \\
\text { population }\end{array}$ & $\begin{array}{l}\text { Area } \\
\left(\mathrm{km}^{2}\right)\end{array}$ & $\begin{array}{l}\text { Density of } \\
\text { population }\end{array}$ \\
\hline \multirow{4}{*}{ East Zone } & Vardar & \multirow{4}{*}{681252} & \multirow{4}{*}{13183} & \multirow{4}{*}{51.7} \\
\hline & East & & & \\
\hline & North-east & & & \\
\hline & South-east & & & \\
\hline \multirow{3}{*}{ West Zone } & Pelagonia & \multirow{3}{*}{770413} & \multirow{3}{*}{10476} & \multirow{3}{*}{73.5} \\
\hline & Polog & & & \\
\hline & $\begin{array}{l}\text { South- } \\
\text { west }\end{array}$ & & & \\
\hline $\begin{array}{l}\text { Agglomerati } \\
\text { on Skopje } \\
\text { region }\end{array}$ & Skopje & 601057 & 1718 & 349.9 \\
\hline
\end{tabular}

Table 1 shows that the East zone covers the largest area and that it has the lowest density of population, but the Skopje region agglomeration has a large density of population in many urban media of relatively small areas. In any case, attention should be paid specifically to the Skopje region agglomeration due to the large number of inhabitants who live in a small territory.

\section{Methods and data sets used for evaluation}

For preliminary evaluation of air quality, three main methods and tools can be applied individually or in combination:

- Measurements of air quality;

- Inventories of air emissions:

- Modelling of air pollution.

Measurements of air quality are used to define the quality of air, particularly in those places where one can expect exceedence of boundary values and/or places where information on emissions is inappropriate. Data from inadequate measurements can be used complementarily. Uncertainties in respect to data from the monitoring can be expected if the monitoring equipment is maintained and calibrated inappropriately, the data are not validated, the stations are not representative which results in a big difference between the quality of air in the environment and the quality of air at the station, or the concentrations considerably vary in the course of time, while the measurements are characterized by a limited time coverage. For the purposes of the presented evaluation of air quality, data on air quality obtained by continuous measurements in the period 2005 - 2010 were used. The main uncertainties regarding the measured data on air quality are influenced by the lack of correction and validation of data and, in the last three years, irregular maintenance of the analyzers due to lack of spare parts, which resulted in reduced coverage.

The data from the inventories of emissions enable initial evaluation of the areas characterized by a risk of exceedence of boundary values. The inventories of emissions can be incomplete or based on inaccurate or improper emission factors or data on the level of activity. The lack of national emission factors for some SNAP sectors represents the main reason for the uncertainty of the used data from the inventory of emissions. The quantities of emissions in a number of sectors are computed through the emission factors stated in the EMEP CORINAIR Instructions. There is a need for an improved coverage with data on emissions, particularly on the traffic and, to a smaller extent, combustion of wood. This will enable comprehensive information about the sources and emissions per zone.

Modeling of air pollution serves for connection of air quality with emissions in a quantitative sense and it enables a better basis for description of areas of exceedence in entire zones. This also provides additional information on management of air quality in the zone. Modeling can result in uncertain results due to the uncertainty of input data as are the meteorological data or the data on emissions, due to improper description or computation of atmospheric processes and concentrations that are obtained in that way. The main uncertainty of the results from the modeling used in this report is associated with the availability of reliable data on the frequency of traffic and emission factors for computation of emissions from them, accuracy and completeness of data on emissions from point sources as well as quality of the data from meteorological observations.

\subsection{Measurement of Air Quality \\ 3.1.1. Zones and Evaluated Regime}

In accordance with the directives of the European Union, the member countries are obligated to define zones that cover their entire territory for evaluation and managing the air quality. The zones mainly represent units for management of air quality, but the directives prescribe also requirements for evaluation per zone. The air pollution levels are evaluated to define the requirements for methods of continuous evaluation of the zones. These requirements depend on how much these levels of air quality are below the boundary value. For each polluting substance, two thresholds are defined: upper threshold of evaluation (UAT) and lower threshold of evaluation (LAT). The thresholds are lower than the ultimate value and are defined as percentages of it.

The requirement for evaluation of the zone depends on whether, in the previous years, the evaluation threshold has 
been exceeded somewhere in the zone. The initial regime of evaluation depends on the results from the Preliminary estimation. If UAT of a certain polluting substance is exceeded, the strictest requirements for evaluation are applied for that polluting substance. If LAT is exceeded but not UAT, a somewhat less strict evaluation requirements are prescribed. If the levels are below LAT everywhere, the lest strict evaluation requirements are applied. Accordingly, the exceedence of the boundary value does not define the evaluation requirements. With these is directed the notification on air quality and actions for its management. In the subsequent figure, it can be seen that Regime 1 is intended for those areas where the concentrations are above the upper evaluation threshold. Regime 2 is for areas where the concentrations are between the upper and the lower evaluation threshold, while Regime 3 is for areas where the concentrations are below the lower threshold of evaluation.
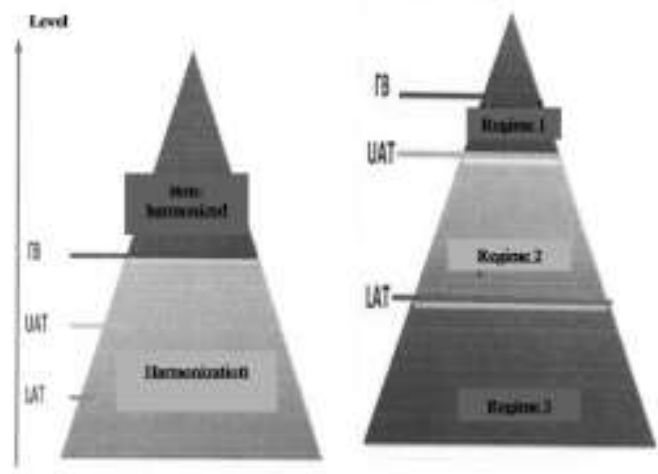

Fig. 3: Implication of exceedence of GB, UAT and LAT for evaluation of harmonization and the requirements for evaluation in a zone.

\subsubsection{Measuring Networks for Air Quality}

In the Republic of Macedonia, monitoring of quality of ambient air is done automatically, at fixed monitoring stations and by manual taking of specimens at several measuring locations. The measurements are done by the following institutions: Ministry of Environment and Physical Planning and the Institute for Public Health through the centres for public health shown in Table 2.

Table II: Methods Used For Measurement Of DifFerent Parameters OF AIR QUALITY

\begin{tabular}{|l|l|l|}
\hline $\begin{array}{l}\text { Air quality } \\
\text { parameters }\end{array}$ & Network & Measuring method \\
\hline $\mathrm{SO}_{2}$ & $\begin{array}{l}\text { Ministry of } \\
\text { Environment } \\
\text { and Physical } \\
\text { Planning }\end{array}$ & $\begin{array}{l}\text { MKS EN 14212:2005 Air quality - } \\
\text { Standard method for measuring of } \\
\text { concentration of sulfur dioxide by } \\
\text { ultraviolet fluorescence }\end{array}$ \\
\hline $\mathrm{SO}_{2}$ & $\begin{array}{l}\text { Institute for } \\
\text { Public Health }\end{array}$ & $\begin{array}{l}\text { Reflectometry, standard British method - } \\
\text { acidometric, West - GAEKE method }\end{array}$ \\
\hline $\mathrm{Dark}$ smoke & $\begin{array}{l}\text { Institute for } \\
\text { Public Health }\end{array}$ & $\begin{array}{l}\text { Reflectometry, standard British method - } \\
\text { photometry }\end{array}$ \\
\hline $\begin{array}{l}\text { NOx } \\
\mathrm{NO}\end{array}$ & $\begin{array}{l}\text { Ministry of } \\
\text { Environment } \\
\text { and Physical } \\
\text { Planning }\end{array}$ & $\begin{array}{l}\text { MKS EN 14211: Air quality - Standard } \\
\text { method for measurement of the } \\
\text { concentration of nitrogen dioxide and } \\
\text { nitrogen monoxide with } \\
\text { chemiluminescence. }\end{array}$ \\
\hline $\mathrm{PM}_{10}$ & $\begin{array}{l}\text { Ministry of } \\
\text { Environment }\end{array}$ & $\begin{array}{l}\text { Automatic monitoring station. Reduction } \\
\text { of beta: x-ray absorption in substance }\end{array}$ \\
\hline
\end{tabular}

\begin{tabular}{|c|c|c|}
\hline & $\begin{array}{l}\text { and Physical } \\
\text { Planning }\end{array}$ & $\begin{array}{l}\text { compared with MKS EN 12341: 2007 Air } \\
\text { Quality - Definition of C410 (PM10) } \\
\text { suspended hard particles - Referent } \\
\text { method and procedure for demonstration of } \\
\text { referent harmonization of measuring } \\
\text { methods. } \\
\text { Device for taking samples: MKS EN } \\
\text { 12341:2007 Air quality - Definition of } \\
\text { PM }_{10} \text { fraction of suspended hard particles. }\end{array}$ \\
\hline $\mathrm{CO}$ & $\begin{array}{l}\text { Ministry of } \\
\text { Environment } \\
\text { and Physical } \\
\text { Planning }\end{array}$ & $\begin{array}{l}\text { MKS EN 14626:2005 Air quality - } \\
\text { Standard method for measuring } \\
\text { concentration of carbon monoxide with } \\
\text { non-dispersive infrared spectroscopy. }\end{array}$ \\
\hline $\mathrm{O}_{3}$ & $\begin{array}{l}\text { Ministry of } \\
\text { Environment } \\
\text { and Physical } \\
\text { Planning }\end{array}$ & $\begin{array}{l}\text { MKS EN 14625:2005 Air quality - } \\
\text { Standard method for measurement of } \\
\text { concentration of ozone with ultraviolet } \\
\text { photometry. }\end{array}$ \\
\hline $\begin{array}{l}\mathrm{Pb}, \mathrm{Cd}, \mathrm{Ni} \\
\mathrm{As}, \mathrm{Zn}, \mathrm{Cr} . \\
\mathrm{Hg}, \mathrm{V}, \mathrm{Mn}, \\
\mathrm{Mg}, \mathrm{Cu} \text { and } \\
\mathrm{Fe}\end{array}$ & $\begin{array}{l}\text { Ministry of } \\
\text { Environment } \\
\text { and Physical } \\
\text { Planning }\end{array}$ & $\begin{array}{l}\text { MKS EN 14902:2005 Air quality - } \\
\text { Standard method for measurement of lead, } \\
\text { cadmium, arsenic and nickel in a fraction } \\
\text { C410 (PM10) of suspended hard particles } \\
*\end{array}$ \\
\hline $\mathrm{Pb}, \mathrm{Zn}, \mathrm{Cd}$ & $\begin{array}{l}\text { Institute for } \\
\text { Public Health }\end{array}$ & $\begin{array}{l}\text { Passive taking of specimens. Partially in } \\
\text { accordance with MKS EN 14902:2005 Air } \\
\text { Quality - Standard method of } \\
\text { measurement of lead, cadmium, arsenic } \\
\text { and nickel in a fraction C410 (PM10) of } \\
\text { suspended hard particles. }\end{array}$ \\
\hline
\end{tabular}

* The procedure described in this standard has been used for analysis of all heavy metals. In accordance with the MKS En standard 14905:2005, heavy metals are analyzed from the collected fraction of $\mathrm{PM}_{10}$. $\mathrm{PM}_{10}$ fraction is taken from the air by use of cellulose filters, in the course of 24 hours. Then, the filters are dissolved in a mixture of $\mathrm{HNO}_{3}$ and $\mathrm{H}_{2} \mathrm{O}_{2}$. Subsequently, the solution in which the heavy metals are dissolved is filtrated and analyzed. The following heavy metals: $\mathrm{Pb}, \mathrm{Cd}, \mathrm{Ni}, \mathrm{Zn}, \mathrm{Cr}, \mathrm{V}, \mathrm{Mn}, \mathrm{Mg}, \mathrm{Cu}$ and $\mathrm{Fe}$ are defined by ICP OES - Perkin Elmer As with AAS and HG with cold vapour AAS.

** In accordance with the MKS EN standard 14905 heavy metals are analyzed from a collected fraction of $\mathrm{PM}_{10}$. $\mathrm{PM}_{10}$ fraction is taken from the air by use of cellulose filters in the course of 24 hours by a passive device for taking samples (1.5$2.5 \mathrm{~m} 3$ air) Then the filters are dissolved in a mixture of $\mathrm{HNO}_{3}$ and $\mathrm{H}_{2} \mathrm{O}_{2}$. Subsequently, the solution in which the heavy metals are dissolved is filtrated and analyzed. The following heavy metals: $\mathrm{Pb}, \mathrm{Cd}$ and $\mathrm{Zn}$ are defined by ICP-OES Perking Elmer.

\section{Monitoring of ambient air}

It should be noted that this report contains data on the quality of air at Karposh and Centar stations in the period 2005 - 2008 and stations Mrshevtsi and Miladinovtsi in the period 2009-2010. The reason for this is the relocation of the Karposh and Centar stations in Mrshevtsi and Miladinovtsi in 2008. Two new stations were located in Karposh and Centar in 2011 but on other locations. Considered in this report are data on the main polluting substances from the automatic monitoring stations since the measuring methods at the manual stations within the frames of the ESW network do not comply with the Rulebook on the methodology of monitoring of ambient air. 
5. Evaluation of $\mathrm{SO}_{2}, \mathrm{NOx}, \mathrm{CO}, \mathrm{PM}_{10}$ and OZONE PER ZONE

\subsection{Sulfur Dioxide (SO2)}

\subsubsection{Emissions}

The annual concentrations of $\mathrm{SO}_{2}$, divided per SNAP sectors for the period $2001-2009$ are shown in Figure 5.

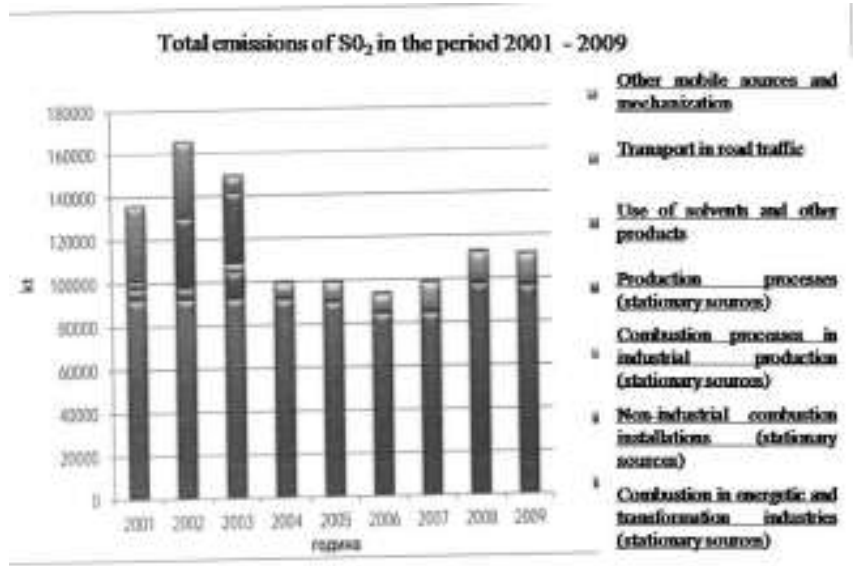

Fig. 5: Total emissions of $\mathrm{SO}_{2}$ in the period 2001-2009

85 to $90 \%$ of the $\mathrm{SO}_{2}$ emissions in Macedonia are the result of emissions during combustion of fossil fuels for production of electricity in thermal power plants that use coal (REK Bitola and REK Oslomej) and absence of devices for desulfurization for reduction of such emissions. There is a decreasing trend of quantities of $\mathrm{SO}_{2}$ in the period 2002 to 2004 and stable and small changes with the reduction and increase of quantities in the period 2004 to 2011, as shown in the graph. The biggest contributor is the sector for production of electric and thermal energy SNAP 01 and $0_{2}$, the next is the sector for industrial production SNAP 03 with combustion of fuels and the sector for road traffic SNAP 07 and the sector for other machines SNAP 08 with a smaller contribution.

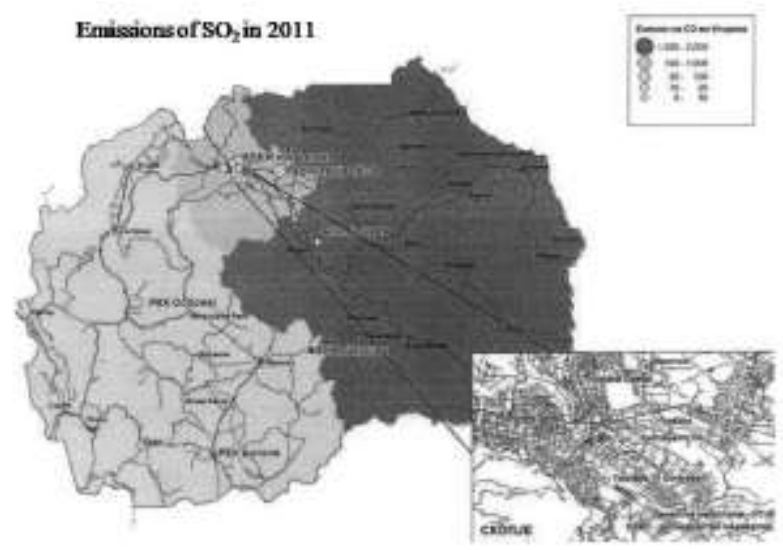

Fig. 6. Emissions of $\mathrm{SO}_{2}$ from big point sources in 2011

This map shows the biggest energy producers - REK Bitola and REK Oslomej with large combustion installations located in the west zone and producing power by use of lignite. With their operation, these large installations contribute to the air pollution and release of large quantities of $\mathrm{SO}_{2}$.
In the Skopje region agglomeration, several large installations for production of heating energy can be noticed. These installations produce energy that is used for heating the households in the winter period and are one of the biggest polluters of air. The factories for production of iron and steel, the refinery and the cement industry also contribute to the emissions of this polluting substance.

The main source of $\mathrm{SO}_{2}$ in the east zone represents FENI industry for production of ferro-nickel. In this zone, there is the thermal power plant TEC Negotino that is not working continuously.

\section{CONCLUSION}

The average annual yearly concentrations of $\mathrm{SO} 2$ for the period $2005-2010$ are represented for each zone in the subsequently presented graphs. To protect the vegetation, a critical level of $20 \mu \mathrm{g} / \mathrm{m}^{3} \mathrm{SO}_{2}$ has been defined for the average values in a calendar year and for the winter period. The critical level will be used only for the rural background areas. Lazaropole represents the only rural background station and the concentrations in Lazaropole are below the critical level.

It can be noticed that the highest average concentrations in the Skopje region agglomeration were observed in the beginning of the analyzed period, while after 2008, the concentrations of $\mathrm{SO}_{2}$ have been decreasing. The decreasing trend has partially been due to the adaptations of the zero level of instruments in the stations that has been going on since 2008. The reduction of the $\mathrm{SO}_{2}$ concentrations has also been due to the introducing of mazut with maximum concentration of sulfur of $1 \%$. The highest concentrations were observed in Karposh municipality in 2007 , with the measured $36 \mu \mathrm{g} / \mathrm{m}^{3}$.

\section{REFERENCES}

[1] European Agency for Reconstruction.: Strategy of environmental monitoring, Skopje, 2004, p. 210.

[2] Krstevska A., Stefanovska A., Vilarova M., Golubov N.: Report on estimation of air quality in Republic of Macedonia, Skopje, 2012, p. 114.

[3] Nork Energy: Building local capacities for development of climate changes projects -CDM, Skopje, 2008, p. 63.

[4] UNEP.: Post-conflict estimation of the environment-Macedonian case, Skopje, 2000, p. 88. 